\title{
Model for glaciotectonism
}

\author{
JAMES S. ABER
}

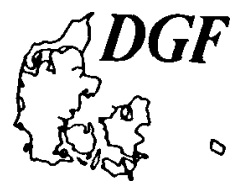

Aber, J. S.: Model for glaciotectonism. Bull. geol. Soc. Denmark, vol. 30, pp. 79-90. Copenhagen September 1st, 1982. https://doi.org/10.37570/bgsd-1981-30-08

Dislocated, thrusted, and folded masses of soft bedrock and drift have been described throughout the glaciated portions of central North America and northem Europe, and the origin of these surficial deformations has mainly been settled in favor of glacioteconic causes. The model for glaciotectonic deformation described here consists of two stages: (1) initial stage of proglacial or ice-marginal thrusting and stacking of large floes during glacier advance over permafrozen terrain, and (2) subsequent stage of subglacial shearing and penetrative deformation of previously-thrusted floes, when ice overrides the area. Ice thrusting takes place along a basal permafrost décollement, where high pore-water pressure is developed, and floes are pushed as permafrozen slabs forward and upward in front and beneath the toe of the advancing glacier to form a topographic ridge (Stauchmoränen or kuppelbakke). Once the ice overrides the ridge of thrusted floes, subglacial deformation by basal shearing may create glaciodynamic mélange. Most glaciotectonic disturbances are thought to develop in a largely frozen state, and the possibility of large-scale subglacial thrusting beneath thick ice or far back from the ice margin is generally believed negligible. The majority of severe glaciotectonic deformations in central North America and northem Europe are found in transitional zones, which separate the central glaciated zones characterized by deep glacial erosion from marginal zones, where glacial deposition was the rule. Glacial thrusting provides a mechanism for stripping sedimentarycover off the Canadian and Fennoscandian shields during repeated Pleistocene glaciations.

J. S. Aber, Geoscience Department, Emporia State University, Emporia, Kansas 66801, U.S.A. February 18 th, 1982.

\section{Introduction}

Dislocated masses of soft bedrock and drift displaying large overturned folds and thrust faults have been described throughout the glaciated portions of central North America and northern Europe. Early controversy over the origin of these surficial deformations has largely been settled in favor of glaciotectonic causes (Jessen 1931, Gry 1940, Kupsch 1962, Moran 1971,Bethelsen 1979). However, as recently as the 1930's some geologists (Hintze 1937) maintained that crustal movements - true tectonism were involved in these deformations. And recently, this idea has been resurrected in modified form by Maddirazza (1979), who noted that salt diapir movement may have localized the development of ice-induced deformations in northcentral Europe.

In central North America, series of icethrusted ridges, resembling end moraines but composed of dislocated floes (allochthonous masses) of bedrock and drift, are found best developed in Alberta and Saskatchewan in Canada and in North Dakota in the United States (Moran, Clayton, Hooke, Fenton and Andriashek 1980). A great many other glaciotectonic disturbances have been reported as far south as Kansas (Dellwig \& Baldwin 1965), and eastward to New England (see Moran 1971 for review). In northem Europe, similar ice-pushed ridges are commonly found in England and the Low Countries on the west and across the southern Baltic region to the east. Wel-known localities include: Norfolk, England (Banham 1975), Rhenen, the Netherlands (Ruegg 1981), the northeastern Netherlands (de Jong 1967), Rügen in northeastern Germany (Brinkman 1953), and several sites in Denmark (fig. 1). Møns Klint in southeastern Denmark is especially noteworthy (fig. 2). These deformations date from all major Pleistocene glacial periods, and many similar glaciotectonic structures have been reported from Paleozoic and Precambrian glaciations (see Edwards 1978 for review).

Having accepted a glacial origin for these deformed sequences, study is now directed toward a fuller understanding of the conditions of forma- 


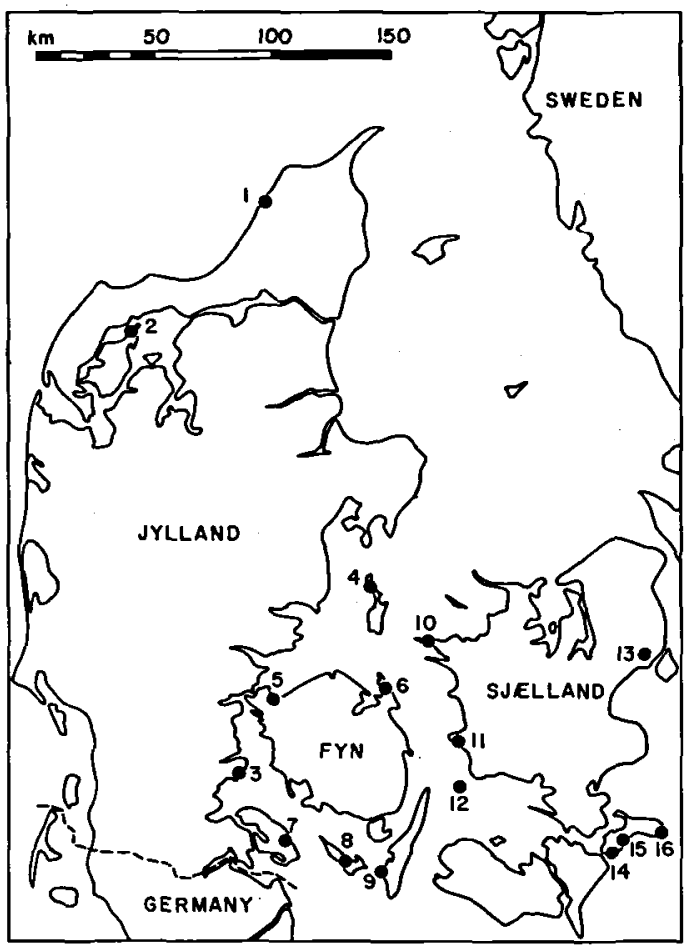

Fig. 1. Map showing locations of well-known or important glaciotectonic sites in Denmark: 1 = Lonstrup Klint (Jessen 1931), 2 = Hanklit and Feggeklit on Mors (Gry 1940), $3=$ Halk Hoved (Jessen 1930), 4 = northern Samsø (HoumarkNielsen 1976), 5 = Røgle and Båring (Smed 1962), $6=$ Hindsholm (Rasmussen 1975), $7=$ Als (Sjørring 1977), $8=$ Erø (Smed 1962), 9 = Ristinge Klint on Langeland (Rosenkrantz 1944), $10=$ Røsnæs (Berthelsen 1975), $11=$ Korsør (Nielsen 1980), 12 = Omø (Jacobsen 1976), 13 = Valby (Ussing 1913), 14 = Madsesklint on Mon (Berthelsen, Konradi \& Petersen 1977), 15 = Hvideklint and Vagtbo Bakke on Møn (Aber 1979, Berthelsen 1979), 16 = Møns Klint (Hintze 1937, Haarsted 1956, Surlyk 1971).

tion and timing of glaciotectonic disturbances. For example, the orientations of fold axes and thrust-fault planes are often used as directional indicators to determine the sense of former glacier movement (Dellwig \& Baldwin 1965). A combination of glacial stratigraphy and structural analysis - called kineto-stratigraphy - is now employed to unravel complexly deformed Quaternary sequences in Denmark (Bethelsen 1973, 1978; Houmark-Nielsen 1981). Recently, Andrews (1980) has attempted to reconstruct paleoclimatic conditions on the basis of glaciotectonic thrusting in upstate New York, U.S.A.

Still, some problems of interpretation remain regarding the exact mechanisms by which glaciotectonic thrusting, folding, and other deformations developed during the Pleistocene glaciations. Many geologists believe that largescale thrusting took place in permafrozen sediments and soft bedrock in front of advancing glaciers (Gripp 1929, Jessen 1931, Gry 1940, Nielsen 1967, Berthelsen 1979), and the thickness of thrust slices is taken as a measure of the depth of permafrost over which the ice sheet advanced. Conversely, other geologists maintain that large-scale dislocations occurred beneath advancing glaciers as slabs of the substratum became frozen to the base of the ice and them were

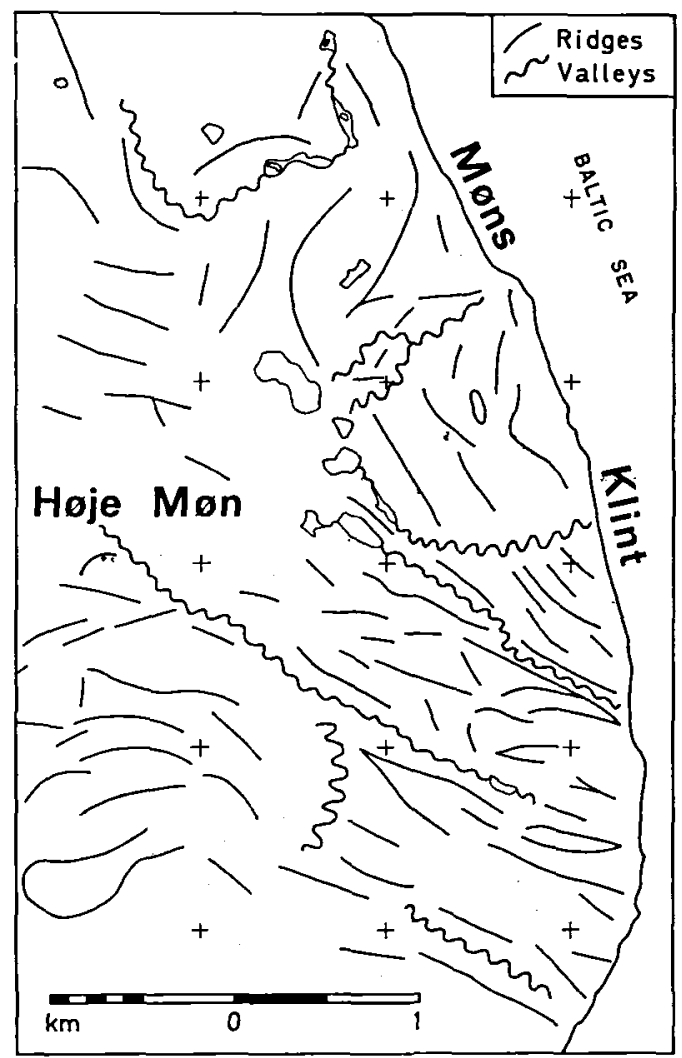

Fig. 2. Map showing ice-thrusted ridges of eastern Møn (locality 16 of fig. 1). A series of thrusted floes consisting of Cretaceous chalk and overlying Quaternary strata are exposed in Møns Klint ( $>100 \mathrm{~m}$ high) and can be traced inland as sharp ridges separated by narrow valleys eroded in drift. Northern section is thrusted southwestward, whereas southern section is thrusted northward. A central section is complexly deformed and displays many short, offset ridges. At least two Weichselian ice advances are indicated, one coming from the northeast, and the other moving from the south. Map based on analysis of topographic maps and aerial stereophotographs. 
carried forward and upward into an englacial position before final deposition (Slater 1927a \& b, Richter 1929, Moran 1971, Clayton \& Moran 1974, Edwards 1978).

Glaciotectonism has a significance beyond strictly glacial geology, since ice-thrusted structures represent a natural scale-model of "thinskinned" tectonics observed in thrust belts of many mountains (Banham 1975). Classic examples include the Appalachian valley and ridge province, the Canadian Rockies front range, and the Helvetic Alps. Gravity sliding and crustal compression have both been suggested as forces that could produce nappes and large overthrusts in orogenic zones, and argument among structural geologists concerning variations of these two mechanisms still continues. Similar largescale thrusting and folding is also developed by soft-sediment deformation, as in the case of mudlumps around the Mississippi delta (Morgan, Coleman \& Gagliano 1968). The mudlumps form as diapiric intrusions and thrusts in prodelta clays immediately in front of the growing delta-front sand deposits.

\section{Theories for glaciotectonism}

\section{Subglacial Thrusting}

Moran (1971) has given the most complete analysis for the concept that large-scale thrusting and dislocations occur subglacially. He stated;

"Large-scale block inclusion of bedrock and drift includes shearing of large masses of material up into the ice and transporting them more or less intact away from the area of décollement. This process involves a combination of the proper hydrogeologic and hydrologic conditions in the bed below the glacier to produce low shear strength and compressive flow in the basal zone of the glacier". (1971, p. 145).

This style of detachment and movement of bedrock and drift floes presumably takes place beneath the ablation zone of the glacier where compressive ice flow produces and upward component to ice movement. In addition, outward groundwater movement may produce excess pore-water pressure in confined aquifers beneath the glacier. This excess pressure facilitates slip- page and shear failures leading to the development of a décollement as the overlying material is incorporated en masse into the base of the advancing glacier (Moran 1971, fig. 5). The detached block may or may not be frozen. However, it is thought that chances for the development of excess hydrostatic pressure are best where the ice sheet advances over permafrost, which would act as a confining layer below which excess pore-water pressure could build up (Clayton \& Moran 1974).

More recently, Moran et al. (1980) have proposed a modified subglacial thrusting theory (see also Banham 1975, fig. 6) in which thrusting takes place only in the thin marginal zone (2-3 $\mathrm{km}$ wide) where the glacier advances over permafrost. Slices of permafrost may become detached from the substratum, frozen onto basal ice, and thus transported forward. The permafrost floes move in a generally basal (not englacial) position beneath the glacier toe.

Several investigators (Moran 1971, Clayton \& Moran 1974, Moran et al. 1980) have applied the subglacial-thrusting concept to explain icepushed ridges in the Missouri Coteau of Alberta, Saskatchewan, and North Dakota. The Missouri Coteau is a broad upland underlain by poorly consolidated Cretaceous shales, siltstones, and sandstones, which presented a topographic barrier to southwestward ice-sheet movements. As the ice sheet thickened and advanced over the northeastern escarpment of the Coteau, supposedly compressive flow with an upward component developed. Zones of excess groundwater pressure could have also developed in confined aquifers beneath the Coteau, leading to slippage and detachment of large floes, which were then incorporated into the moving glacier. A permafrost layer in front and beneath the edge of the advancing ice sheet would have aided this process.

\section{Proglacial Thrusting}

Another school of thought has accepted a mechanism of proglacial thrusting to explain large-scale glaciotectonic dislocations (Gripp 1929, Jessen 1931, Gry 1940, Nielsen 1967, Berthelsen 1979, van der Wateren 1981). The importance of permafrost in front of the advancing glacier has been stressed by many geologists. 
For example, in reference to ice-induced thrusting in the Netherlands, de Jong (1967, p. 341) stated:

“Considering the glaciotectonic structure and the lithological character of the ice-pushed material, namely sands and clays, it is probable that the faults, folds, and overthrusts only originated when the sands and clays were in a frozen state".

Dylik (1967) came to the same conclusion in central Poland regarding monoclinal structures formed by lateral pressure of advancing glaciers, and Kupsch (1962) also reached the same conclusion concerning ice-pushed ridges in western Canada.

The base of the permafrost is, thus, seen as the plane of décollement. Groundwater moving outward from beneath the ice and trapped beneath the permafrost could build up to high pressures in the sediment pores, allowing for easy slippage and movement of the overlying frozen material. In this situation, the advancing glacier would act as a bulldozer, pushing and stacking permafrozen floes in front of the ice margin (Nielsen 1967, fig. 264 , Berthelsen 1979, fig. 5a). The permafrozen thrust slices are never incorporated into an englacial position, but simply pushed out in front of the glacier toe. With this interpretation, the thickness of individual thrust floes reflects the depth of permafrost over which the ice sheet transgressed (Richter et al. 1951, de Jong 1967).

Gripp's (1929) observations around glaciers on Spitzbergen demonstrated that proglacial thrusting of ridges does occur at the ice margin. He introduced the German term "stauchmoränen", meaning push-moraine, to describe ice-thrusted ridges. In addition, proglacial thrusting has been modeled experimentally using snow layers by Gry (1940). It has also been argued (Gry 1940) that the forward and especially upward movement of large floes detached from the substratum could not occur subglacially. While forward movement due to subglacial drag might occur, the weight of the overlying glacier would prevent upward movement of huge slabs of material - compressional flow or not.

The concept of proglacial thrusting of permafrozen floes has most often been applied to European examples of ice-pushed ridges, for there is abundant evidence that permafrost existed in a wide periglacial zone during the major glaciations of northern Europe (Dylik 1967, Nielsen 1967, Paepe \& Pissart 1969, Maarleveld 1976). For example, de Jong (1967, p. 341) estimated that permafrost $50 \mathrm{~m}$ to $100 \mathrm{~m}$ thick existed in the Netherlands in front of the advancing Saalian ice sheet. Also, regarding ice-thrusted ridges in the Missouri Coteau of Canada, Kupsch (1962, p. 593) suggested, “. ... an origin in the zone of glacier thrusting near the terminus under thin ice exerting a light static pressure, and also possibly in front of the ice."

\section{Penetrative Glacial Deformation}

Whatever the exact mechanism of large-scale glacial thrusting, this style of deformation is not penetrative; the displacements are mostly confined to narrow thrust zones, while internal structure of individual floes is frequently well preserved. A different style of glaciotectonic deformation involves masses of material, including both drift and bedrock, which have been chaotically mixed together, pervasively sheared, folded, and refolded. The resulting material displays a metamorphic foliation and resembles tectonic mélanges; in fact, the term "glaciodynamic mélange" has been used to describe such deposits (Aber 1979). A glaciodynamic mélange, thus, represents material intermediate in character between glacially deformed bedrock and true, homogeneous till, and so corresponds to the zone of penetrative glacial deformation of Banham (1977). It is generally agreed that this small-scale style of ice-induced deformation occurred subglacially due to shearing movement at the base of the glacier (Moran 1971), and it seems likely that the affected material was at least partly, if not largely, frozen when deformation took place (Aber 1979, Berthelsen 1979).

\section{Basal Ice Sheet Conditions}

Any attempt to interpret glaciotectonic deformation must include a consideration of the conditions existing at the base of the ice sheet when the deformations develop. In particular, whether or not the substratum is frozen and the presence or absence of basal meltwater seem of great importance.

Clayton \& Moran (1974) have outlined a 
"process-form model" for ice-sheet glaciation, which includes three thermal zones: (1) proglacial permafrost zone, (2) marginal frozen-bed zone, ad (3) central thawed-bed zone. The ice sheet is the pressure-melting point beneath the thick, central accumulation zone, but near the thinner edge the ice sheet becomes frozen to the permafrost over which the ice is advancing. Groundwater movement is generally outward from the thawed-bed zone beneath the frozenbed zone. Large-scale thrusting, they believe, would occur mainly at the position where the ice sheet becomes frozen to the substratum. This position could be either relative close or far behind the ice margin.

Hooke (1977) has also investigated this problem and came to slightly different conclusions. Considering conditions of ice thicknesses, accumulation rates, and surface temperaures, he developed ice-sheet models that generally showed the central accumulation zone would be frozen at its base, while basal melting would occur beneath the ablation zone. This would appear to conflict with the process-form model described above; however, Hooke $(1977$, p. 9) does note that:

"Near the margin, where the ice thins rapidly, the amount of basal melting decreases again, and within a few hundred meters of the margin the glacier is again frozen to its bed".

This conclusion is also supported in the recent theoretical analysis by Moran et al. (1980), who envision a narrow (2-3 km wide) frozen ice margin behind which basal meltwater is found.

Regardless of the various theoretical models for ice-sheet flow, field evidence from both Europe and North America supports the conclusion that major glaciations did advance initially over permafrost. For example, Mickelson \& Clayton (1981) recently described a model, based mainly on geomorphic evidence, for the late Wisconsin Green Bay lobe of the Laurentide ice sheet. The terminal toe $(2-10 \mathrm{~km}$ wide) of the lobe was apparently frozen, and periodically subglacial meltwater derived from upice catastrophically broke through the frozen margin creating tunnel valleys.

\section{Model for Glaciotectonism}

The model for glaciotectonism presented here includes two stages: (1) early stage of proglacial or ice-marginal thrusting and stacking of large floes during ice sheet advance over permafrozen terrain, and (2) later stage of subglacial shearing and penetrative deformation of previously-thrusted floes, when the ice sheet overrides the area (Aber 1981).

\section{Glaciotectonic Thrusting}

Thrusting begins as an ice sheet is rapidly growing and advancing over permafrozen terrain consisting of soft bedrock or sediments (fig. 3A). This situation could develop at the onset of a major glaciation or during readvance following an interstade. Although the ice sheet is frozen to the permafrost near its margin, where ice flow is compressive, basal meltwater is available some distance behind the ice margin. This basal meltwater, produced by frictional and geothermal heat, tends to move outwards as groundwater toward zones of lower pressure beyond the ice margin. Additional outward groundwater movement may be fed by water forced out of pores in soft sediments, which are compacted by the weight of the advancing glacier. The result is a zone of potential excess hydrostatic pressure developed beneath the permafrost layer under the glacier toe and beyond the ice margin.

Thrust faults develop along this weakened zone of high pore-water pressure due to the increased weight and forward motion of the advancing ice sheet. Hence, the base of the permafrost becomes a décollement along which thrust-slices are pushed out in front of the glacier. Individual thrusts follow the basal permafrost décollement and then curve upward cutting through the permafrost layer. The result is a series of wedgeshaped floes, each floe thickest in the center and thinner to the front and rear, which are pushed over each other (Jessen 1931). Where thrusts cut upward to the surface, it is thought that some meltwater from below and from pressure-melting along the thrust itself may provide lubrication for easy slippage.

Lateral variations in permafrost thickness 
$\sim \sim \perp \quad$ Permafrost layer

$\nabla \nabla \nabla \quad$ High pore-water pressure

A

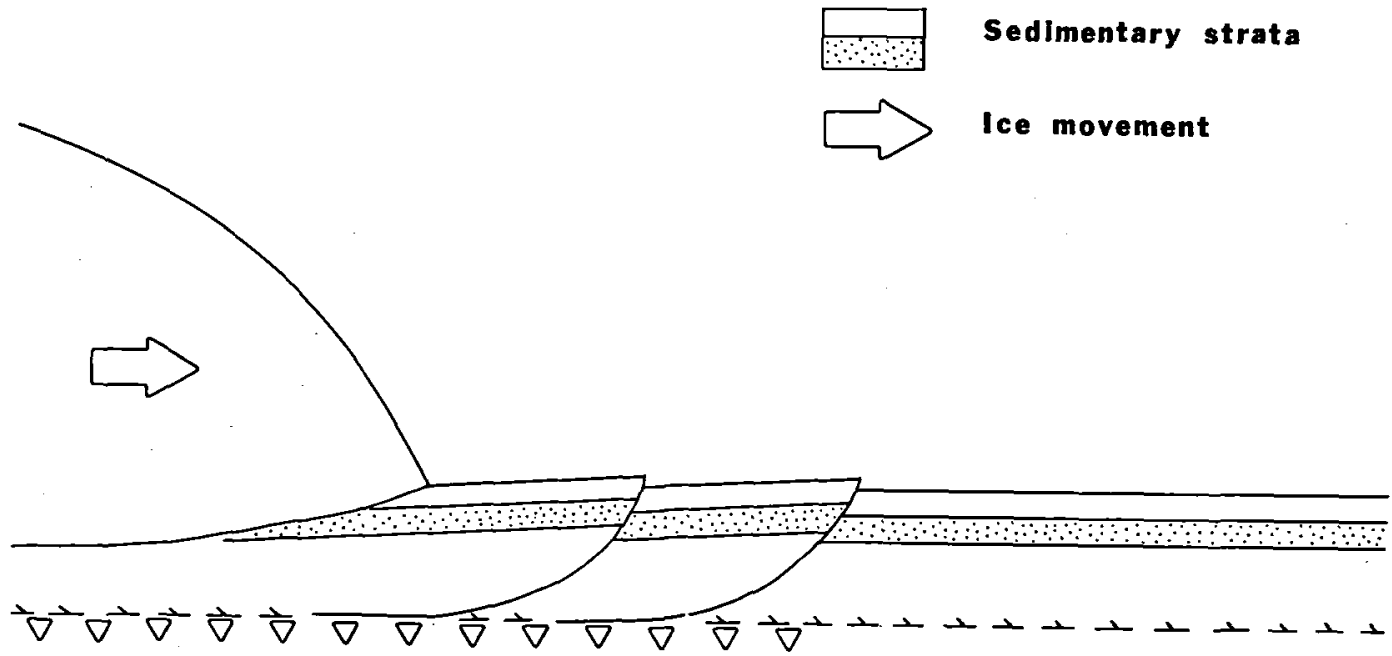

B

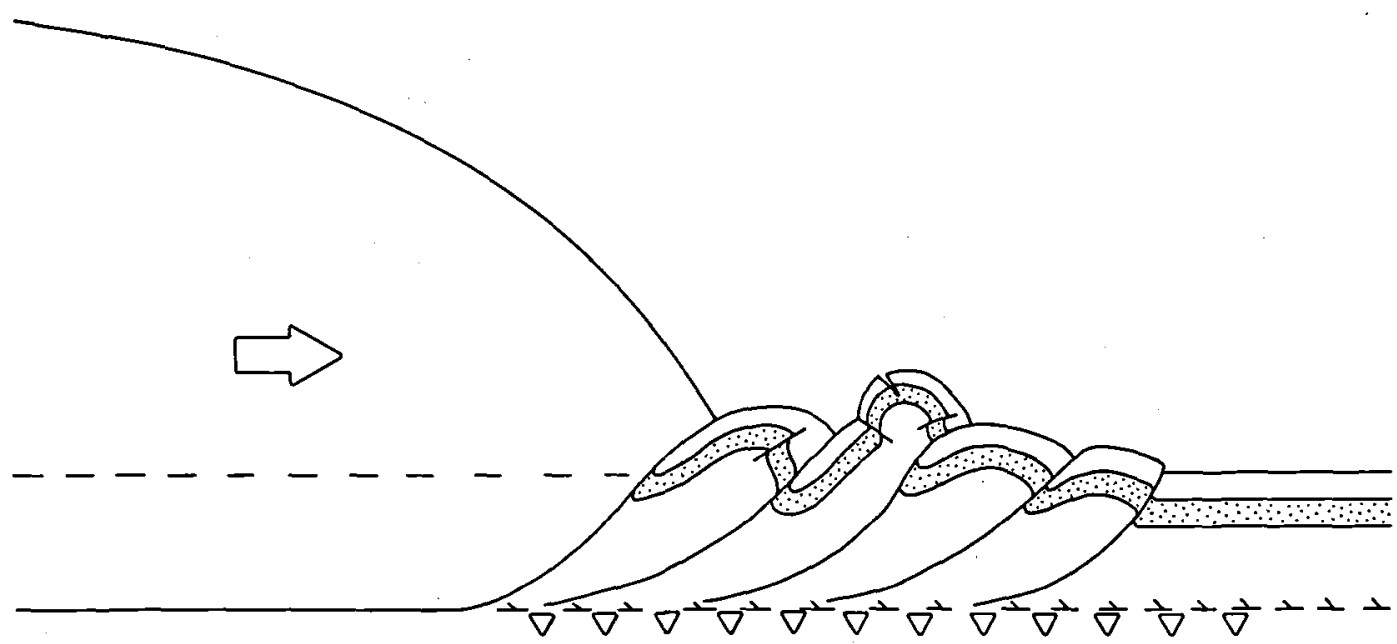

Fig. 3. Idealized sequential model for glaciotectonism. (A) Initiation of thrusting along basal permafrost décollement below toe and in front of advancing glacier. (B) Stacking of permafrozen floes below toe and in front of advancing glacier to form topographic barrier. (C) Resistant barrier of permafrozen floes overridden by glacier and subjected to subglacial shearing. (Not to scale.)

probably influence the development of initial thrusting - thrusting of thin or discontinuous permafrost would occur more readily than where thicker. Thicker zones of permafrost could resist thrusting and be overridden by the advancing ice sheet. Overridden permafrost would then be subjected to intense subglacial shearing, as de- scribed in a later section. Local topography would also influence the initiation of thrusting. Banham (1975) has noted that compressional glaciotectonic structures are usually found where the advancing ice sheet moved against the landslope. Typical settings include valley sides, escarpments, and islands or peninsulas. 
C

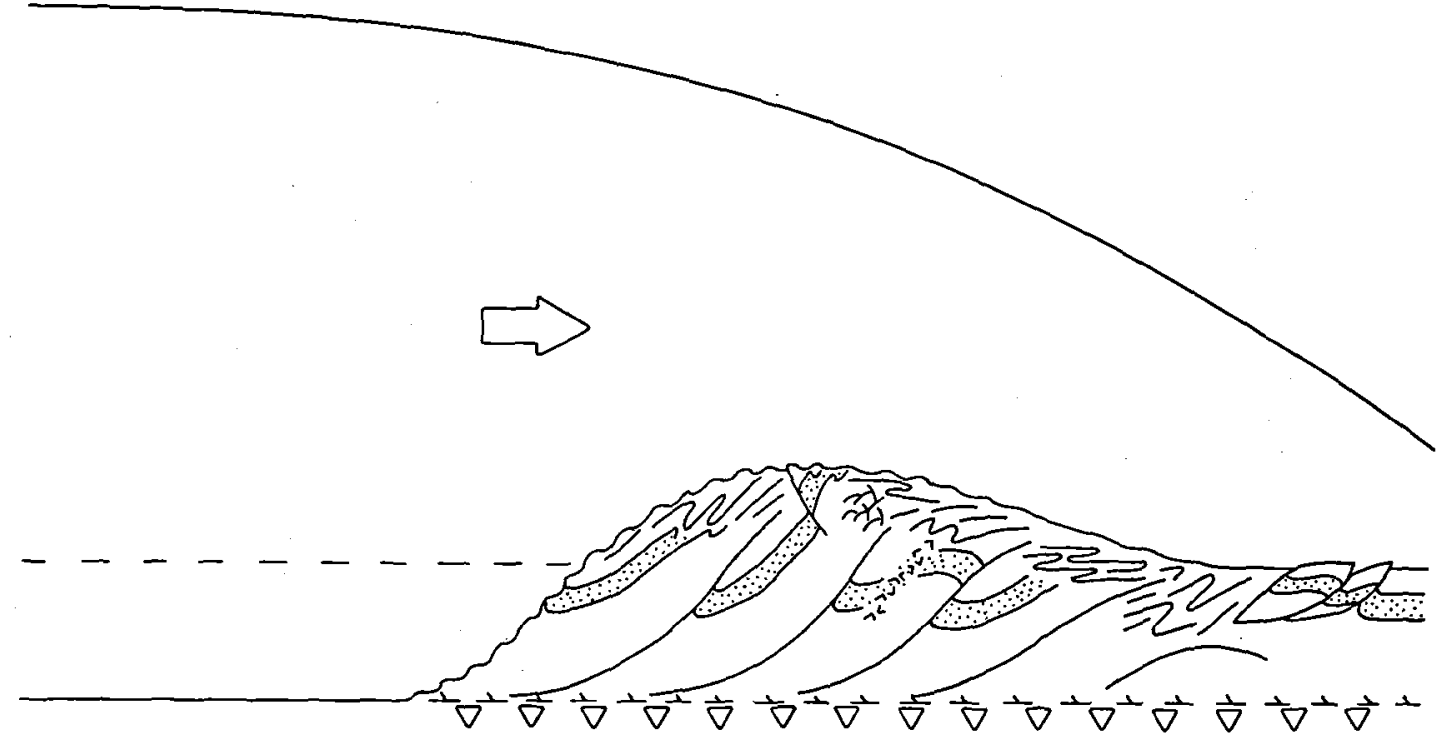

As ice-sheet advance and thrusting continue, a series of floes begins to stack up in an imbricated pattern in front and beneath the toe of the ice (fig. 3B). This thrusting has a dominolike development; new thrusts appear in front of older thrusts as ice movement pushes the older floes forward and upward causing increased loading and stress on the basal permafrost décollement. Individual floes are usually folded into general synclinal anticlinal forms, which often become overturned in a downice direction, and drag folds may develop along thrust faults. Near the crests of some floes, underthrusting and open fissures sometimes appear as the floe becomes overturned. Although most displacements occur along major thrustsm some internal deformations folds, faults, and brecciation - may take place due to differential stresses induced within the floes. In due time, the stacking of floes begins to build a topographic barrier or ridge, which hinders forward ice movement, so ice flow is diverted around this self-made obstacle.

Eventually, the topographic barrier of thrusted permafrozen floes grows large enough to resist additional forward pushing by the advancing ice sheet, or it may become lodged on a more resistant substratum, such as thicker permafrost or stronger bedrock, and the ice overrides the bar- rier (fig. 3C). Once the permafrozen floes are covered by thicker ice, further large-scale subglacial thrusting does not seem likely, since ice flow would become generally parallel or extending as the ice thickened (Clayton \& Moran 1974, fig. 1c). The wide basin behind the barrier has been created by the forward thrusting and removal of the permafrost layer, and thus the basin represents the source area for the floes. Within this basin, basal meltwater allows for easy forward movement of the ice sheet, while the ice is still frozen at its base over the thrusted ridge. The depth of the basin is roughly equal to the thickness of the former permafrost layer, as is the thickness of individual floes.

\section{Subglacial Deformation}

Concentrated ice flow (not basal slippage) over and around the still frozen, thrusted barrier now results in a penetrative, shearing style of deformation and perhaps some erosion of the barrier (fig. 3C). All material in the ridge as well as drift in the basal ice becomes mixed, folded, and refolded creating a chaotically sheared mass - a glaciodynamic mélange. Smaller floes may be broken off, carried downice, and emplanted on the lee side of the ridge (Banham 1975). Most of 
this kind of smaller-scale subglacial deformation is usually restricted to the upper few meters or tens of meters of the barrier. However, if subglacial shearing and erosion continue over a long time period, the earlier ridge may be greatly reduced in size until not easily recognizable. As in the earlier case of large-scale thrusting, it is thought that the materials are largely frozen when subjected to subglacial shearing, with only minor quantities of water produced by pressuremelting present.

Yet another style of subglacial deformation may also develop in the basin behind the thrusted ridge. With the removal of the permafrost layer and loading by a thick ice mass, any soft and saturated sediments could be subjected to fluidlike deformations. Especially in fine-grained sediments, the hydrostatic pressure due to ice loading may exceed the mechanical strength of the sediment, leading to failure and fluid flowage of sediment masses. The result is a variety of intrusive (diapiric) sedimentary structures reminiscent of various shallow plutonic rocks (Berthelsen 1974, Moran et al. 1980).

\section{Long Profile}

Having created and advanced over an icethrusted ridge, the ice sheet continues to move onward, and the whole process may be repeated over again. Eventually, a series of ice-pushed ridges separated by wide, low basins develops, creating a "glaciotectonic landscape". In idealized profile view (fig. 4), it is seen that basins are several times wider than ridges, which form prominent hilly areas rising tens to hundreds of meters above the surrounding lowlands. The ba- sins are generally a few to several tens of $\mathrm{km}$ in width. In map view, the ridges often display an arcuate pattern, convex in the direction of thrusting, outlining the configuration of the ice lobe which caused the thrusting (fig. 2). The landscape described here is particularly common in several portions of Denmark (Nielsen 1967, Fig. 264), where Smed (1962) has applied the Danish term "kuppelbakke", meaning dome- or cupula-hill, to the ice-thrusted ridges on the island of Fyn. Similar landscape development is also quite common in the Missouri Coteau of Alberta, Saskatchewan, and North Dakota (Moran et al. 1980).

\section{Conditions of Thrusting}

Ice-marginal thrusting will not take place under all conditions of glacier advance. A particular set of conditions, where an ice sheet with a frozen margin and warmer interior advances rapidly over soft, permafrozen strata, is thought best for the development of thrusting. If the substratum consists of hard bedrock or is frozen to great depth, some erosion may occur, but not largescale thrusting. On the other hand, a soft, unfrozen bed would be too weak to support thrusting, and a thorough mixing of the material (till) would result. A substratum consisting of soft rocks or sediments permafrozen in the upper several tens of meters is the ideal situation for proglacial thrusting of permafrozen floes. Thrusting could occur where an ice sheet advanced over continuous or discontinuous permafrost. In the latter case, large "permafrozen islands" might by rafted long distances by ice pushing over a thawed substratum. This may explain how large, horizontal

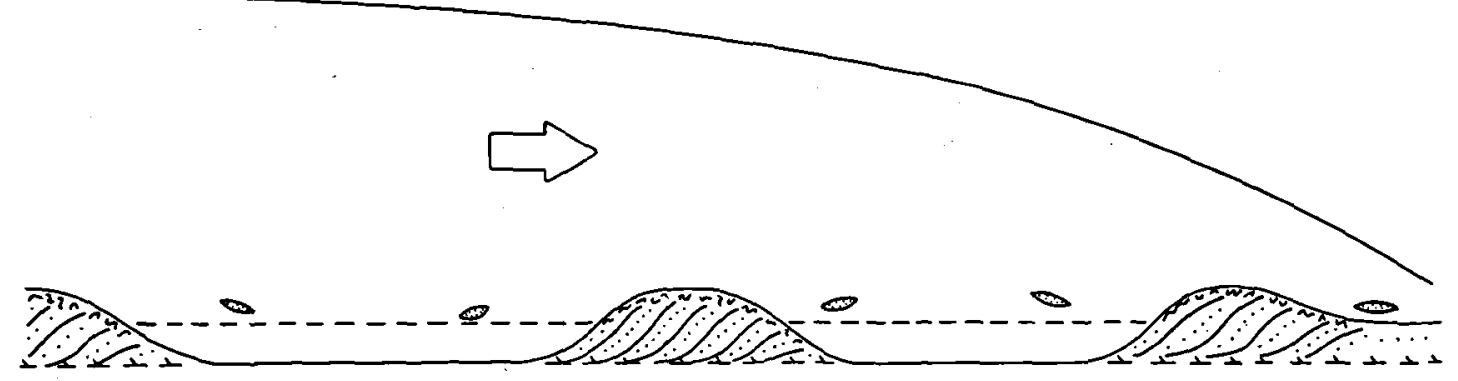

Fig. 4. Long profile of idelalized "glaciotectonic landscape" showing series of narrow, ice-pushed ridges consisting of permafrozen floes separated by wide basins from which the permafrost layer has been removed by glacial thrusting. (Not to scale.) 
floes are transported many $\mathrm{km}$ from their sources.

Regarding ice temperature conditions, both a cold-based ice sheet, which is frozen to its bed everywhere, and a temperature ice sheet, where basal meltwater is present at the margin, are considered unsuitable to produce ice thrusting. The former usually involves glaciers with rather sluggish movement, and the absence of basal meltwater limits the chances for zones of excess hydrostatic pressure to develop in the substratum. The latter often includes fast-moving glaciers, but basal meltwater can escape fairly readily around the ice margin, and so again high pore-water pressure is unlikely to develop in the substratum. The ideal situation is developed where the ice margin is frozen to a permafrost bed, but basal meltwater is present behind the margin in a thawed-bed zone. In this case, excess hydrostatic pressure may develop beneath the marginal permafrost layer, leading to potential detachment and thrusting. Finally, a rapidly advancing ice sheet is more apt to cause glacial thrusting than a slowly advancing one; rapid loading and high shear stresses would accompany a vigorous, fast advance.

\section{Discussion of Model}

The model for glaciotectonism just described assumes that large-scale thrusting takes place proglacially or beneath the thin glacier toe and not beneath thick ice. The following arguments are offered in support of this view:

(1) The relative timing of deformations, where discernable, often indicates a proglacial origin for large-scale thrusting. For example in northwestern Jylland, Denmark, Jessen (1931) and Gry (1940) have shown that proglacial outwash deposited during glacier advance was subsequently thrusted. Following the episode of thrusting, these structures were partially truncated by overriding ice, and finally covered by a mantle of lodgment till.

(2) Certain minor structures sometimes found in ice-thrusted ridges, such as fissures along anticlinal axes (Surlyk 1971) and underthrusting of overturned folds (Jessen 1931, Surlyk
1971), probably could only develop under a light static load - that is not under thick ice.

(3) "The individual floes in the disturbed areas are in relationship to their original positions pushed both forward and upward. It is unthinkable, that this can happen under the pressure of an overlying ice sheet." (Gry 1940 , p. 616 , translated) To push large floes upward at the margin of an advancing glacier, though is entirely reasonable, since there would be little overburden.

(4) Large ice-thrusted floes have been reported from the extreme limits of glaciation, for example south of the Kansas River valley in west-central U.S.A. (Dellwig \& Baldwn 1965). This proves that ice pushing can and does occur at the ice margin and is not restricted to the area coveredby thicker ice.

(5) It is easy to comprehend how a series of floes could stack up in an imbricated pattern during ice-marginal thrusting. This style of deformation has been experimentally modeled (Gry 1940) and observed in front of modern glaciers (Gripp 1929). How such an imbricated pattern could develop in a simple manner on a large scale due to subglacial movement is more difficult to visualize.

(6) In the past, ice-thrusted ridges were often mistaken for true end moraines (Moran 1971), because of their arcuate of lobate pattern. The morphologic similarity or icepushed ridges and true moraines could suggest that both developed at the ice margin. Ice-thrusted ridges might be interpreted as marking ice-margin positions during glacier advance (Moran et al. 1980, p. 466).

On this basis, it is concluded that most large-scale glaciotectonic thrusting develops at and immediately in front of advancing glacier margins. This is not to say subglacial thrusting may never take place, for it probably does occur under the frozen toe (2-3 km wide) of a glacier (Kupsch 1962, Moran et al. 1980). Nevertheless, it is thought that subglacial thrusting occurs only very close to the leading edge of an advancing glaciernot under a thick mass of ice or far back from the ice margin as some geologists may have earlier envisioned.

Many geologists have recognized that within individual series of thrusted ridges the intensity of 
deformation is often greatest on the stoss side and decreases toward the lee side (Slater 1927c, Gry 1940, Beyers 1960, Kupsch 1962, fig. 4). This is readily explained by ice-marginal pushing and stacking, where the stoss-side floes are pushed longest and directly by the glacier, while outer floes are pushed indirectly for a shorter time span. The result is steeper dips of stoss-side thrusts and shallower dips on the lee side (fig. 3C).

In some cases, for example at Møns Klint (Haarsted 1956) and Hvideklint (Aber 1979, Berthelsen 1979) on the island of Møn, Denmark, the opposite situation is developed. There, the intensity of deformations increases from a minimum on the stoss sides of disturbed zones, where massive, thrusted, but little folded chalk floes are found, to a maximum toward the lee sides, where chalk floes are greatly stretched and folded together with drift forming glaciodynamic mélanges. Within the extremely deformed zones, Berthelsen (1979) has identified large boudinage structures. This is explained as due to subglacial deformation of the chalk floes, once the advancing ice sheet had overridden the area. Indeed, the form of ice-pushed ridges may be greatly modified by any number of later erosional, depositional, or deformational processes. Proglacial thrusting may, in fact, be a very common phenomenon during ice sheet advance over permafrozen strata. However, this has not been generally recognized, because in many cases later subglacial processes have modified or destroyed the proglacial structures and landforms.

As previously noted, most geologists believe that large-scale thrusting must have involved frozen blocks of material. Moran (1971, p. 134) on the other hand suggested that:

"Undoubtedly, in some instances, the (subglacially) included blocks have been frozen at the time of their incorporation, but this is not a necessary prerequisite for incorporation if the porewater pressure in the subjacent beds was sufficiently high".

Supposedly, if excess pore-water pressure is developed in confined aquifers, then unfrozen blocks of material may be picked up as floes by the glacier. However, one could ask; how is it possible that unfrozen floes of soft rock or sediment could be incorporated into the base of a glacier? The floes must become frozen; otherwise the material, saturated with meltwater, would be thoroughly churned by shearing producing homogeneous drift. It is here believed that most glaciotectonic deformations, both proglacial and subglacial, develop in a largely frozen condition with only small amounts of meltwater present. The one exception is the fluidlike deformation that can develop in unfrozen soft sediments beneath thick ice masses, as previously described.

The close similarity between ice-pushed structures and thin-skinned tectonics has been noted often; the only real difference between the two is scale of development. Certainly, the overall driving force for glaciotectonic dislocations is nothing more than gravity acting on the mass of the ice sheet (Berthelsen 1979). It is only on the frozen toe of an advancing glacier where compressive stress may develop to cause ice-marginal thrusting. This set-up for glaciotectonism corresponds to Elliott's (1976) analysis of thin-skinned orogenic thrusting. He concluded that gravitational forces dominate in emplacement of thrust sheets, while compressive forces are important only in thrust-sheet toes.

Glaciotectonic dislocations of sediment and bedrock are not found in equal abundance throughout glaciated terrains. In central North America and northern Europe, they are most common in the zones underlain by Cretaceous and Tertiary sedimentary bedrock surrounding the vast shield regions. Large glaciotectonic disturbances are less common near the outer limits of glaciation, where glacial deposition was the rule, and they are still rarer in the shield areas, where glacial erosion was the dominant process. Hence, overall, the distribution of strong glaciotectonic disturbances forms a transitional zone between regions of glacial erosion and glacial deposition. Any overall model of continental ice-sheet glaciation should, then, include three general zones: (1) central zone of deep glacial erosion with most soft cover materials stripped away to expose basement rocks (zones $1 \& 2$ of White 1972), (2) transitional zone marked by large-scale glaciotectonic deformations of soft bedrock, and (3) marginal zone of predominant glacial deposition burying the preglacial landscape. Proglacial thrusting was probably an important mechanism for progressively stripping sedimentary cover off the shields during repeated Pleistocene glaciations. 


\section{Conclusions}

(1) The origin of glaciotectonic folding, thrusting, and deformation may be understood in terms of a two-stage model. The first stage of deformation includes large-scale thrusting of permafrozen floes in front and under the toe of an advancing glacier. Ice-thrusted floes then stack up forming a topographic barrier, which is eventually overridden by the ice. At that point, a second stage of subglacial deformation by penetrative shearing of still largely frozen material takes place.

(2) The possibility of large-scale subglacial thrusting behind the marginal zone is generally discounted. It is thought that glacial thrusting mostly occurs below the toe or immediately in front of advancing ice sheets - not beneath thick ice masses as some geologists may have believed.

(3) A "glaciotectonic landscape" consists of a series of narrow, high, arcuate ridges composed of ice-pushed floes separated by wide, low basins, which represent the source areas for the dislocated floes. The ice-thrusted ridges may be interpreted as marking ice-margin positions during glacier advance.

(4) Severe glaciotectonic disturbances are most common in the zones of sedimentary strata surrounding the shield areas of central North America and northern Europe, and less common in marginal areas or central areas of glaciation. A model for continental ice-sheet glaciation, thus, includes three zones: (1) central zone of predominant glacial erosion, (2) transitional zone of glaciotectonic disturbances, and (3) marginal zone characterized by glacial deposition.

Acknowledgements. This study was begun under a FulbrightHays Grant for geological studies in Denmark at the University of Copenhagen, and further supported by the Research Institute of Chadron State College, Nebraska, and by Emporia State University, Kansas. I thank all of my collegues at the Institute for General Geology, University of Copenhagen, especially Prof. A. Berthelsen, who contributed greatly to this report through many discussions, reviews, and field trips. My wife, Susie, ably assisted with field work in Denmark during 1979. Wakefield Dort, Jr. reviewed this report and offered several helpful criticisms.

\section{Dansk sammendrag}

Geologer har beskrevet større isbetingede (glacialtektoniske) deformationer af moraner og bløde bjergarter (kalk, ler, sandsten, o.s.v.) fra glacialterrænerne i Nordamerika og Nordeuropa. I denne artikel presenteres en model for glacialtektonisme, der består af to faser: (1) oppresning af større permafrosne flager foran den fremrykkende is og under isens randzone, og (2) senere fase af gennemtrængende (penetrativ) subglacial deformation, når isen har rykket frem over landskabet. Isoverskydningerne finder sted langs grænsezonen, hvor forhøjede porevandstryk dannes, mellem permafrostlaget og den ikke-frosne undergrund, og permafrosne flager er skubbet op i enkuppelbakke|(stauchmoræne) foranisen. Efterhånden' 'glider isen hen over kuppelbakken, og subglacial deformation frembringer glaciodynamic mélange. Dannelsen af disse glacialtektoniske deformationer finder sted sandsynligvis mens bjergartmaterialet er permafrossent, dog kan små mængder smeltevand dannes ved tryksmeltning i overskydningszonerne. Det er tankeligt, at flagoppresningen af kvartære gletschere har borteroderet bløde prækvartære bjergarter i Skandinavien og Canada, hvor man nu finder de canadike og fennoskandiske grundfjeldsskjolde.

\section{References}

Aber, J. S. 1979: Kineto-stratigraphy at Hvideklint, Møn, Denmark and its regional significance. Bull. geol. Soc. Denmark 28: 81-93.

Aber, J. S. 1981: Two-Stage Model for Glaciotectonism. Geol. Soc. America, Abst, with Program 13: 393.

Andrews, D. E. 1980: Glacially thrust bed rock - An indication of late Wisconsin climate in westem New York State. Geology 8: 97-101.

Banham, P. H. 1975: Glacitectonic structures: a general discussion with particular reference to the contorted drift of Norfolk. In: Wright, A. E. \& Moseley, F. (eds.): Ice Ages: Ancient and Modern. Geol. Journal, Special Issue No. 6, Steel House Press, Liverpool, England, p. 69-94.

Banham, P. H. 1977: Glacitectonics in till stratigraphy. Boreas 6: 101-105.

Berthelsen, A. 1973: Weichselian ice advances and drift successions in Denmark. Bull. geol, Inst. Univ. Uppsala N. S. 5: 21-29.

Berthelsen, A. 1974: Nogle Forekomster af Intrusivt Moræneler i NØ-Sjælland. Dansk geol. Foren., Arsskr. 1973: 118-131.

Berthelsen, A. 1975: Geologi på Røsnæs. Varv, Ekskursionsforer 3 .

Berthelsen, A. 1978: The methodology of kineto-stratigraphy as applied to glacial geology. Bull. geol. Soc. Denmark 27, special issue, 25-38.

Berthelsen, A. 1979: Recumbent folds and boudinage structures formed by subglacial shear: An example of gravity tectonics. In: van der Linden, W. J. M. (ed.): Van Bemmelen and his search for harmony. Geol. en Mijnbouw 58: 252-260.

Berthelsen, A., Konradi, P, \& Petersen, K. S. 1977: Kvartære lagfølger og strukturer i Vestmøns klinter. Dansk geol. Foren. Arsskrift 1976: 93-99.

Brinkman, R. 1953: Über die diluvalien Störungen auf Rügen. Geol. Rundschau 41, Sonderband, 231-241.

Byers, A. R. 1960: Deformation of the Whitemud and Eastend formations near Claybank, Saskatchewan. Trans. Royal Soc. Canada 53, ser. 3, sec 4, 1-11. 
Clayton, L. \& Moran, S. R. 1974: A glacial process-form model. In: Coates, D. R. (ed.): Glacial Geomorphology. SUNY Publ. in Geomorphology, Binghamton, New York, p. 89-119.

Dellwig, L. F. \& Baldwin, A. D. 1965: Ice-push deformation in northeastem Kansas. Bull. Kansas Geol. Survey 175, part 2.

Dylik, J. 1967: The Main Elements of Upper Pleistocene Paleogeography in Central Poland. Biuletyn Peryglacjalyn 16: $85-115$.

Edwards, M. B. 1978: Glacial Environments. In: Reading, H. G. (ed.): Sedimentary Environments and Facies. Elsevier, New York, p. 416-438.

Elliott, D. 1976: The Motion of Thrust Sheets. Jour. Geophysical Research 81: 949-963.

Gripp, K. 1929: Glaziologische und geologische Ergebnisse der Hambergischen Spitzbergen-Ekspedition 1927. Abh. Naturw. Verein Hamberg 22: 147-247.

Gry, H. 1940: De istektoniske forhold i moleromraadet. Meddr. dansk geol. Foren. 9: 586-627.

Hintze, V. 1937: Møens Klints geologi. C. A. Reitzel, Copenhagen.

Hooke, R. Leb. 1977: Basal Temperatures in Polar Ice Sheets: A qualitative review. Quaternary Research 7: 1-13.

Houmark-Nielsen, M. 1976: En glacialstratigrafisk oversigt fra Nordsamsø og Tunø. Dansk geol. Foren. Arsskrift 1975: 11-13.

Houmark-Nielsen, M. 1981: Glacialstratigrafi i Danmark ost for Hovedopholdslinien. Dansk geol. Foren. Arsskrift 1980: 61-76.

Haarsted, V. 1956: De kvartære geologiske og geomorfologiske forhold på Møn. Meddr. dansk geol. Foren. 13: 124-126.

Jacobsen, E. M. 1976: En morænestratigrafisk undersøgelse af klinterne på Omø. Dansk geol. Foren. Arsskrift 1976: 15-17.

Jessen, A. 1930: Klinten ved halkhoved. Danm. geol. Unders. IV, rakke 2(8): $26 \mathrm{pp}$.

Jessen, A. 1931: Lonstrup Klint. Danm. geol. Unders. V, rakke 2: $195 \mathrm{pp}$.

de Jong, J. D. 1967: The Quaternary of the Netherlands. In: Rankama, K. (ed.): The Quaternary. J. Wiley \& Sons, New York, 301-426.

Kupsch, W. O. 1962: Ice-Thrust Ridges in Western Canada. Jour. Geology 70: 582-594.

Maarleveld, G. C. 1976: Periglacial Phenomena and the Mean Annual Temperature During the Last Glacial Time in the Netherlands. Biuletyn Peryglacjalyn 26: 57-78.

Maddirazza, I. 1979: Saltdiapirernes betydning for den Kvartare kronologi: Batum - et eksempel. Dansk geol. Foren. Arsskrift 1978: 7-13.

Mickelson, D. M. \& Clayton, L. 1981: Subglacial Conditions and Processes During Middle Woodfordian Time in Wisconsin. Geol. Soc. America, Abst. with Program 13: 310.

Moran, S. R. 1971: Glaciotectonic Structures in Drift. In: Goldthwait, R. P. (ed.): Till/a Symposium. Ohio State Univ. Press, p. 127-148.
Moran, S. R., Clayton, L., Hooke, R. Leb., Fenton, M. M. \& Andriashek, L. D. 1980: Glacier-Bed Landforms of the Praire Region of North America. Jour. Glaciology 25: $457-476$.

Morgan, J. P., Coleman, J. M. \& Gagliano, S. M. 1968: Mudlumps: Diapiric Structures in Mississippi Delta Sediments. In: Braunstein, J. \& O'Brien, G. D. (eds.): Diapirs and Diapirism. Amer. Assoc. Petrol. Geologists, Memoir 8: 145-162.

Nielsen, A. V. 1967: Landskabets Tilblivelse. In: Nørrevang, O. \& Meyer, T. J. (eds.): Danmarks Natur, Bd 1, Landskabernes Opståen. Politikens Forlag, Copenhagen, p. 251-344.

Nielsen, P. E. 1980: Kvartærgeologiske undersøgelser i Korsørområdet. Dansk geol. Foren. Arsskrift 1979: 55-62.

Paepe, R. \& Pissart, A. 1969: Periglacial structures in the LatePleistocene stratigraphy of Belgium. Biuletyn Peryglacjalyn 20: 321-336.

Rasmussen, L. Aa. 1975: Kineto-stratigraphic glacial drift units on Hindsholm, Denmark. Boreas 4: 209-217.

Richter, K. 1929: Studien über fossile Gletscherstruktur. Zeitschr. für Gletscherkunde Bd XVIII, Berlin.

Richter, W. H., Schneider, H. \& Wager, R. 1951: Die Saaleeiszeitliche Stauchzone von Itterbeck-Uelson. Zeitschr. Deutsch. Geol. Ges. 102: 60-75.

Rosenkrantz, A. 1944: Nye bidrag til forståelsen af Ristinge Klints opbygning. Meddr. dansk geol. Foren. 10: 431-435.

Ruegg, G. H. 1981: Ice-pushed Lower and Middle Pleistocene deposits near Rhenen (Kwintelooijen): sedimentarystructural and lithological/granulometrical investigations. Meded. Rijks Geol. Dienst 35-2, p. 165-177.

Slater, G. 1927a: The disturbed glacial deposits in the neighborhood of Lönstrup, near Hjörring, North Denmark. Trans. Royal Soc. Edinburgh LV, part II, 303-315.

Slater, G. 1927b: The structure of the disturbed deposits of Møens Klint, Denmark. Trans. Royal Soc. Edinburgh LV, part II, 289-302.

Slater, G. 1927c: Structure of the Mud Buttes and Tit Hills in Alberta. Bull. Geol. Soc. America 38: 721-730.

Sjørring, S. 1977: The glacial stratigraphy of the island of Als, southern Denmark. Z. Geomorph. N.F., Suppl.-Bd. 27: 1-11.

Smed, P. 1962: Studier over den fynske ogruppes glaciale landskabsformer. Meddr. dansk. geol. Foren. 15: 1-74.

Surlyk, F. 1971: Skrivekridtklinterne på Møn. Varv, Ekskursionsforer 2: 5-24.

Ussing, N. V. 1913: Danmarks geologi. Danm. Geol. Unders., række III, nr. 2.

van der Wateren, F. M. 1981: Glacial tectonics at the Kwintelooijen Sandpit, Rhenen, The Netherlands. Meded. Rijks Geol. Dienst 35-7, p. 252-268.

White, W. A. 1972: Deep erosion by continental ice sheets. Bull. Geol. Soc. America 83: 1037-1056. 